\title{
Hvordan kan KRLE-faget fremstille islams mangfold?
}

\section{Av Dag Hallvard Nestby}

I denne artikkelen gir jeg et bidrag til den faglige diskusjonen om hvordan islam kan fremstilles i grunnskolens KRLE-fag. Ved hjelp av Robert Jacksons tredelte tilncerming til religion prøver jeg å vise at lareplanens syn på menneskerettigheter som en felles referanse åpner et problematiserende rom hvor elevers ønske om nyanserte fremstillinger av islam kan imøtekommes. Jeg redegjør først for innholdet $i$ Jacksons metode; deretter redegjør jeg for noen problematiserende stemmer (innen islam) som viser muslimenes bidrag til en felles forståelse av menneskerettighetenes betydning. Til slutt undersøker jeg hvorvidt slike stemmer kommer til uttrykk i KRLE-fagets to nyeste larebøker (for ungdomstrinnet). Undersøkelsen viser stor variasjon i forekomsten av slike stemmer.

Nøkkelord: Islam, KRLE-fagets læreplan, menneskerettigheter, Robert Jacksons tredelte tilnærming, rettighetsfremmende strømninger, KRLE-boka 8-10, Store spørsmål 8-10

Dag Hallvard Nestby (f. 1976), Universitetslektor dr. philos. ved Institutt for filosofi og religionsvitenskap, NTNU. Adresse: NTNU, Institutt for filosofi og religionsvitenskap, 7491 Trondheim.

E-post:dag.nestby@ntnu.no

\section{INNLEDNING}

Helt siden KRL ble innført i 1997, har fagpersoner diskutert hvordan ikke bare kristendommen, men også andre religioner og livssyn kan fremstilles i undervisningen. Diskusjonen har ofte dreiet seg om islam på grunn av den islamske tradisjonens problematiske status i mediebildet. I de senere år har det offentlige ordskiftet om integrering av minoritetsgrupper i stor grad blitt en debatt om muslimer og deres muligheter til å bli fullverdige medlemmer av et demokratisk fellesskap (Furseth 2015; von der Lippe og Undheim 2017, s. 22-24). Marie von der Lippe har vist at ungdommer preges av denne debatten. I sin forskning får hun frem at elever ofte reproduserer et medieskapt syn på muslimer som antimoderne og fundamentalistiske. Samtidig får hun frem at de samme elevene $\emptyset$ nsker mer nyanserte representasjoner av islam (von der Lippe 2010, 2013; von der Lippe og Undheim 2017, s. 22-24). Denne beskrivelsen bekreftes av Audun Toft. Hans studie viser at medienes negative bilde av islam er til stede i klasserommet, og at elever påvirkes av dette. Samtidig får Toft tydeliggjort at hans informanter oppfatter medienes ensidige vinkling som problematisk (Toft 2019). I denne artikkelen $\emptyset$ nsker jeg å gi et bidrag til denne diskusjonen ved

Prismet - IKO-Forlaget 2019

Tilgjengelig på https://journals.uio.no/index.php/prismet. Publisert under CC BY-NC 4.0. Fagfellevurdert 
å trekke noen didaktiske konsekvenser av sentrale formuleringer i religionsfagets læreplan. Læreplaner uttrykker, som blant andre John Goodlad har presisert (1979), politisk vedtatte føringer og intensjoner for utdannelsessystemet. De gjenspeiler samfunnets overordnede ønsker og gir retningslinjer, blant annet, for hva lærere bør vektlegge i sitt arbeid med de forskjellige fagene. Hva sier den innledende seksjonen i KRLE-fagets læreplan (hvor formålet med faget skisseres) om hva lærere bør vektlegge i sin fremstilling av de religiøse tradisjonene? Læreplanen presiserer at lærere skal formidle kunnskaper om religioner og livssyn på en måte som er saklig, upartisk og respektfull overfor verdisystemenes respektive særpreg. Planen presiserer imidlertid også at lærerne skal bidra til etableringen av felles referanserammer som skal styrke elevenes evne til å kommunisere på tvers av kulturelle og religiøse skillelinjer. Dialogfremmende referanserammer må nødvendigvis inkludere en respekt for religiøse verdier, men også for menneskerettighetene og menneskerettighetenes etiske grunnlag (Utdanningsdirektoratet 2008, 2015). Disse formuleringene anvendes i de to siste læreplanene (som er identiske på nesten alle punkter), og de videreføres i den nye læreplanen (slik den fremstår etter at høringsinnspillene er innarbeidet). I den nye planens første seksjon, «Fagets relevans og sentrale verdier», står det at elevene skal bli kjent med felles dialogfremmende verdier (som relateres eksplisitt til menneskerettighetene og bevissthet om menneskeverdet) og hvordan disse verdiene er forankret i ulike religioner og livssyn (Utdanningsdirektoratet september 2019).

Hvis man forholder seg til disse formuleringene på en konstruktiv måte, så inneholder de en mulig løsning på representasjonsproblemet identifisert av, blant andre, Marie von der Lippe. Disse formuleringene tilsier at lærere ikke bare skal fokusere på religionenes overordnede hovedkomponenter, men at de også skal rette elevenes oppmerksomhet mot strømninger relatert til de respektive tradisjonene som kan, potensielt sett, imøtekomme ønsket om nyanserte fremstillinger. Slike strømninger problematiserer sentrale antagelser og dominerende perspektiver på en slik måte at de skaper grobunn for hermeneutisk åpenhet. Det første spørsmålet som jeg ønsker å besvare, er hvilken strategi lærere bør velge for å gjøre elevene oppmerksomme på slike problematiserende strømninger. I mitt arbeid med dette spørsmålet kommer jeg til å anvende Robert Jacksons fortolkende metode som mitt teoretiske fundament. Jackson forfekter det syn at man innenfor rammene av en moderne og fordomsoverskridende religionsundervisning $b ø r$ ha en tredelt tilnærming til religioner og livssyn. Han anbefaler, både på grunnlag av teoretiske vurderinger og empiriske studier, at lærere nedtoner inntrykket av religioner som klart avgrensede størrelser med et enhetlig innhold, og at de heller presenterer religioner som sammensatte og komplekse tradisjoner. Disse tradisjonene består av 
enkeltpersoner og grupper som vil forholde seg til det overordnede tankegodset på svært forskjellige måter. Gjennom kvalitative analyser av Jacksons religionsbegrep (1997, 2004) ønsker jeg å indikere hvordan KRLE-lærere kan åpne problematiserende rom innen den islamske tradisjonen som viser muslimenes bidrag til en felles forståelse av menneskerettighetenes betydning. Jeg vil, som en del av analysen, gi noen eksempler på slike rettighetsfremmende bidrag. Det neste spørsmålet som jeg ønsker å besvare, er hvorvidt de nyeste lærebøkene innen KRLE-faget (for ungdomstrinnet), nemlig Cappelen Damms KRLE-boka 8-10 (2016) og Aschehougs Store spørsmål 8-10 (2015-2017), legger forholdene til rette for slike nyanserende strategier. Gjennom kvalitative analyser av kapitlene om islam ønsker jeg å klargjøre om lærebøkene indikerer eksistensen av kritiske strømninger.

\section{JACKSONS TREDELTE TILNARMING TIL RELIGIONER OG LIVSSYN - INDIVID, GRUPPE OG TRADISJON}

Robert Jackson tredelte tilnærming går, essensielt sett, ut på at han - i sine analyser av religion - ikke bare fokuserer på et overordnet og enhetlig tradisjonsnivå, men også på de individer og grupper som til sammen utgjør en religiøs tradisjon. Jackson har sin grundigste gjennomgang av denne metoden i kapitel 3 av Religious Education: An Interpretive Approach (1997). Han presiserer først at forståelsen av religioner som avgrensede størrelser med et enhetlig innhold har vært dominerende innen religionsvitenskap helt frem til i dag. Denne forståelsen av begrepet «religion» har sin opprinnelse, i hvert fall til dels, i opplysningstidens tenkning rundt menneskets transcenderende tilbøyeligheter. På 1600-tallet fremmer, blant andre, Lord Herbert av Cherbury tanken om at en religion er et velstrukturert verdisystem med et begrenset antall doktriner som er enten sanne eller falske. Innen midten av 1700-tallet har denne forståelsen av hva en religion er for noe, blitt svært utbredt blant Europas intellektuelle. Begrepet har siden begynnelsen, bemerker Jackson, bidratt til å stimulere konflikter på tvers av kulturelle skillelinjer blant annet ved at anvendelsen av begrepet genererer forenklede og ofte eurosentriske fremstillinger av ikke-vestlige religioner. Jackson noterer, som allerede nevnt, at opplysningstidens oppfatning av fenomenet «religion» er, med noen justeringer, fortsatt utbredt innen religionsvitenskapen, og ikke minst innen religionsdidaktikken. Dette kommer til uttrykk gjennom myndigheters og fagpersoners arbeid med læreplaner, pensumlister og lærebøker i Storbritannia og andre land (Jackson 1997, s. 50-60).

Jackson mener at man innen religionsvitenskapen og religionsdidaktikken bør beholde religionsbegrepet (å fjerne det er urealistisk), men man må kommunisere overfor elever og befolkningen for $\emptyset$ vrig at en religions 
overordnede komponenter (kristendommens ti bud, islams fem søyler, buddhismens fire edle sannheter og så videre) spiller en annen rolle enn det som ofte kommer til uttrykk innenfor det tradisjonelle religionsbegrepet. De sentrale doktrinene utgjør ikke totaliserende rammeverk som alle «trosfeller» aksepterer og internaliserer mer eller mindre ukritisk; de sentrale doktrinene utgjør heller et sett med referansepunkter som et visst antall enkeltpersoner og grupper (med en viss rett) kan sies å ha felles, men som de samtidig behandler på svært forskjellige måter. Hva som avgjør behandlingens karakter, vil variere fra person til person; det vil avhenge av bakgrunn, kunnskapsnivå, erfaringer og holdninger til eksistensielle spørsmål. Som Jackson selv formulerer det:

[T] he tradition [...] will be perceived differently by individuals according to the way of life in which they are operating and their background knowledge and experience, and one's view of the tradition is likely to be modified as one encounters new material. Moreover, «insiders» may have different views from one another of the scope of the tradition and of the relative importance of its different aspects. The precise nature of a religious tradition will be a matter of negotiation or even contest. (Jackson 1997, s. 62-63.)

\section{Den TREDELTE TILNÆRMINGenS SYNLIGgJøRING AV PROBLEMATISERENDE STEMMER}

Det interessante med Jacksons tilnærming er at den frembringer et landskap hvor personer og grupper som utfører tildels gjennomgripende problematiseringer av sentrale trekk ved «sine» religiøse tradisjoner, kan sies å være en del av tradisjonen og derfor ha krav på å bli presentert i en undervisningskontekst. Denne tilnærmingen kan anvendes av lærere som $\emptyset$ nsker å tydeliggjøre det muslimske bidraget til en global menneskerettighetsdiskurs og derigjennom imøtekomme elevers $\emptyset$ nske om nyanserte fremstillinger. Jackson presiserer, i denne sammenhengen, at hans metode ikke innebærer en avvisning av religionenes overordnede komponenter: «The approach does not deny the importance of grasping concepts and practices 》 (Jackson 1997, s. 69). I arbeidet med islam betyr det helt konkret at lærere bør bruke noe tid på å presentere sentrale doktriner som troen på en enhetlig gud og forklare betydningen av de fem søylene. Spørsmålet er om disse definerende trekkene er spesielt rettighetsfremmende. Mange religionsforskere, deriblant Lars Gule (2006) og Ann Elizabeth Mayer (2007), mener ikke det. Islams sentrale doktriner, i deres ortodokse fortolkning, harmonerer ikke med menneskerettighetene (og så presiserer de begge at det samme kan sies om kristendommens sentrale dogmer - i deres tradisjonelle form). Den moderne rettighetstenkningen legger til grunn at mennesket er en, essensielt sett, fri skapning, og at mennesket derfor har en uangripelig rett til å 
handle på selvstendig grunnlag. Retten til å handle selvstendig kombineres med en plikt til å respektere andre menneskers rett til å gjøre det samme (gjensidighetsprinsippet). Dette synet på menneskets frihet, som har røtter i antikken, men som utkrystalliseres gjennom opplysningstiden, er delvis forbundet med en erkjennelse av at det ikke lenger finnes sikre svar på metafysiske spørsmål som alle kan enes om. I en slik situasjon blir det enkeltindividet som i kraft av sin autonomi må finne egne svar på eksistensielle utfordringer - blant annet gjennom valg av livssyn. Opplysningstidens visjon av hvilket handlingsrom et individ kan tillate seg, står, mener Gule og Mayer, i klar kontrast til den forståelsen som islamske teologer, jurister og andre intellektuelle, tradisjonelt sett, har forfektet. Et flertall av skriftlærde har, fortsetter Gule og Mayer, helt frem til i dag forkastet tanken om at mennesket kan kreve en slik grad av frihet. Mennesket har, strengt tatt, ingen rett til autonomi; mennesket har, tvert imot, en forpliktelse overfor Gud til å følge hans forordninger slik de kommer til uttrykk i Koranen og i beretningene om profetens eksemplariske livsstil. Mennesket kan ikke overskride Guds grenser, for eksempel ved å problematisere åpenbaringen eller ved å forlate islam til fordel for et annet livssyn, uten at det får negative konsekvenser. Tradisjonalistene innrømmer mennesket noen partikulære og begrensede rettigheter (Gule og Mayer nevner retten til kompensasjon som et eksempel), men disse rettighetene er ikke avledet fra menneskets status som selvlovgiver; de er avledet fra menneskets forpliktelser overfor Gud (Gule 2006, s. 70-97; Mayer 2007, s. 51-70).

Jacksons metode åpner imidlertid for at muslimske stemmer med en alternativ forståelse av hvordan den islamske tradisjonens forskjellige aspekter bør fortolkes og vektlegges, også kan spille en viktig rolle i undervisningen. Lærere som ønsker å prøve ut en slik tilnærming, kan finne relevante stemmer og tankeretninger både i den islamske tradisjonen og, ikke minst, i dagens diskusjon muslimer imellom. Ser man på tradisjonen, stemmer det nok, som Lars Gule og Ann Elizabeth Mayer presiserer, at et flertall av muslimske lærde har hatt et forholdsvis snevert syn på hvilket handlingsrom mennesket kan tillate seg. Selv de som har fors $\emptyset \mathrm{kt}$ å reformere islam (på forskjellige stadier i religionens historie), har ofte gjort dette på grunnlag av ortodokse fortolkninger. Denne vurderingen bekreftes av, blant andre, Majid Fakhry som i innledningen til sitt anerkjente verk A History of Islamic Philosophy $(1970,1983,2004)$ skriver følgende:

[T] hroughout Muslim history reform movements have not been marked by a great degree of release from authority or dogma or a quest for the reinterpretation or reexamination of fundamental presuppositions in the realms of social organization, theological discussion, or legal thought. Instead, [...] they were marked by a deliberate attempt to 
vindicate the old, Traditionist concepts and assumptions of the earliest protagonists of Muslim dogma, the so-called good forebears (al-salaf al-salih) of the Muslim community. (Fakhry 2004, s. XXII.)

Fakhry presiserer imidlertid at det allerede under Abbaside-perioden fra år 750 til 1258 vokser frem filosofiske retninger hvis representanter går meget langt i å problematisere den ortodokse forståelsen av islamske doktriner (og som derigjennom åpner nye rom for menneskelig utfoldelse). En av de fremste er, ifølge Fakhry, den arabiske filosofen og poeten Abu al-'Ala' al-Ma'arri som avviser det tradisjonelle synet på Muhammeds åpenbaring som en uangripelig kilde til sannhet. Han avviser også jødedommens og kristendommens pretensjoner om å gjenspeile og dermed representere noe absolutt sant - ingen religion kan kreve en privilegert posisjon. Istedenfor å bruke profeter og åpenbaringer som normgivere, så bør mennesket heller bruke fornuften når det skal vurdere både sin egen status og forholdet til andre mennesker (Fakhry 2004, s. 107-108).

Ser man på dagens diskusjon muslimer imellom, så kan man skimte stadig flere fors $\emptyset \mathrm{k}$ på å revurdere de islamske kildene på grunnlag av rasjonalisme og humanisme. Anne Sofie Roald bemerker i sin bok om islam at menneskerettighetsdebatten har blitt mer omfattende i løpet av de siste tiårene, og at denne utviklingen er sammenvevet med fremveksten av en historisk-kritisk fortolkningstradisjon (Roald 2012, s. 190-210). Et dagsaktuelt eksempel fra Norge på et bidrag til denne utviklingen er antologien Islamsk humanisme (2016) hvor blant annet lederen for Oslokoalisjonen for tros- og livssynsfrihet ved Norsk senter for menneskerettigheter ved Universitetet i Oslo, og tidligere leder for Islamsk Råd, Lena Larsen argumenterer - i artikkelen «Islam og menneskerettigheter» - for at de islamske kildene kan fortolkes slik at de harmonerer med moderne rettighetstenkning. Hun underslår ikke det faktum at mange retninger innen den islamske tradisjonen har stått i opposisjon til menneskerettighetene på flere punkter. Konflikten mellom islam og internasjonale menneskerettigheter kan imidlertid overvinnes, mener Larsen, ved at muslimer skiller klarere mellom tradisjonens evige budskap og tidsbestemte normer. Larsen henviser her til den iranske filosofen og teologen Mohsen Kadivar som argumenterer for at det finnes både uforanderlige og foranderlige forskrifter i islam. De uforanderlige forskriftene bekrefter at mennesket har rettigheter i kraft av å være menneske. Disse forskriftene er beskrevet i koranversene fra Mekka-perioden (cirka 610-622), og de støttes av fornuften (som ifølge Larsen og Kadivar er sterk nok til å kunne tjene som målestokk for hvilke koranvers som har evig gyldighet og hvilke som hører fortiden til). De foranderlige forskriftene, på den annen side, er de som skiller mellom menneskers rettigheter basert på deres kjønn, religion og så videre. Disse mer detaljerte og spesifikke forskriftene er beskrevet primært i koranver- 
sene fra Medina-perioden (cirka 622-632); de var hensiktsmessige da profeten skulle bygge opp et nytt samfunn, men på grunnlag av kritisk tenkning kan man konkludere med at disse forskriftene er såpass bundet til en bestemt historisk periode at de har ingen gyldighet utover denne perioden. Fornuften krever andre løsninger i møte med modernitetens utfordringer enn de profeten valgte i Medina (Reiss og Noor 2016, s. 36-63; Vogt, Larsen og Moe 2009, s. 47-73).

\section{Fremstillinger av islam i KRLE-Boka 8-10 OG STORE SPØRSMÅL 8-10}

KRLE-boka 8-10 og Store spørsmål 8-10 er de eneste lærebøkene for ungdomstrinnet som har kommet ut etter innføringen av den siste læreplanen i 2015. Begge verk baserer seg på denne planen, men også til dels på den forrige planen fra 2008, hvis innhold er nesten identisk med den nåværende. I den første underseksjonen av denne seksjonen vil jeg fokusere på KRLE-boka, og så kommer jeg til å fokusere på Store spørsmål i neste underseksjon. Gjennom kvalitative nærlesninger av kapitlene om islam ønsker jeg, som nevnt, å klargjøre om lærebøkene indikerer eksistensen av kritiske strømninger - på individ- og gruppenivå - som kan legge grunnlaget for nyanserte fortolkninger av den islamske tradisjonen. Jeg kommer til å konsentrere meg om de aktuelle kapitlenes brødtekster, men jeg kommer også til å kommentere forfatternes generelle religionsforståelse og illustrasjonene. I en vitenskapelig artikkel om hvilke konsekvenser læreplanens formuleringer kan ha for presentasjonen av islam, anser jeg en slik analyse for å være meget viktig. Forskning tyder på at læreboken fortsatt står sterkt i norsk skole, ikke minst i fag hvor lærernes egne kunnskaper kan komme litt til kort. Læreboken skaper det fundamentet som de pedagogiske aktivitetene baserer seg på (Skrunes 2010; Juuhl, Hontvedt og Skjelbred 2010). Innen KRLE har dette funnet blitt bekreftet av, blant andre, Inger Margrethe Tallaksen og Hans Hodne. I artikkelen «Hvilken betydning har læremidler i RLE-faget?» (2014) presenterer de resultater fra en kvalitativ studie som viser at for religions- og livssynslærere så spiller lærebøkene en stor rolle når læreplanen skal operasjonaliseres. Tallaksen og Hodne presiserer at lærere som har deltatt i deres undersøkelse, også bruker andre didaktiske ressurser, men både i forberedelsene til undervisning og i selve undervisningssituasjonen er læreboken viktigst. Dette betyr - i praksis - at lærebokforfatternes fortolkning av læreplanen adopteres av lærerne (Tallaksen og Hodne 2014).

\section{KRLE-boka 8-10}

Forfatterne av KRLE-boka, Pål Wiik og Ragnhild Bakke Waale, presenterer sin generelle forståelse av religion i åpningskapitlet, «KRLE-faget». En religion fremstilles som et overordnet og retningsgivende svar på eksistensielle spørsmål. 
Tilhørighet til en religiøs tradisjon relateres, i stor grad, til utøvelsen av bestemte aktiviteter. Disse aktivitetene foregår «i kirken, i moskeen, i tempelet eller i synagogen» (Wiik og Waale 2016, s. 9). Det handler om bønn, meditasjon og feiring av religiøse høytider. For noen handler religiøs tilhørighet også om bruk av bestemte klesplagg og symboler. Når forfatterne skal utdype hva som karakteriserer religiøse mennesker, så vektlegger de faktorer som troen på et liv etter døden, troen på én Gud eller flere guder, en vilje eller en kraft, og ønsket om å være med i et fellesskap eller en organisasjon, for eksempel i en menighet (Wiik og Waale 2016, s. 10). Variasjon i hvordan «medlemmene av en religion ut $ø$ ver sin tro» forbindes $i$ all hovedsak med hvor ofte man deltar i religiøse aktiviteter. Mot slutten av kapitlet - under overskriften «Et mangfold» - kommer imidlertid individnivået, slik det defineres i Jacksons analyser, tydeligere til uttrykk:

I møte med [det religiøse] mangfoldet former hvert enkelt menneske sine personlige tanker om tro og livssyn. Noen er trygge og stolte innenfor en religion eller et livssyn. Mange er på leting og plukker litt fra ulike tradisjoner. Både filosofi, film, tv, dataspill, litteratur, internett og sosiale medier gir impulser til å danne sitt eget livssyn eller sin egen tro. (Wiik og Waale 2016, s. 12-13.)

Spørsmålet blir i hvilken grad - og på hvilken måte - individnivået manifesteres i kapitlet om den islamske tradisjonen.

Kapitlet om islam er delt inn i tre underkapitler: «Islam i praksis», «De hellige tekstene og islam i dag» og «Hva muslimer tror på» (kapitlene om jødedommen, hinduismen og buddhismen er delt inn på samme måte). Gjennom de tre delene skaper Wiik og Waale et bilde av islam som en enhetlig og klart avgrenset religion med en relativt homogen tilhengermasse. Forfatterne åpner det første underkapitlet på følgende måte:

En muslim er en som frivillig aksepterer Gud som den høyeste myndighet og at Muhammed er den siste profeten. En muslim tror på Guds engler, Guds skrifter, Guds profeter og livet etter døden. En person som vil bli muslim, må si trosbekjennelsen og virkelig mene det. (Wiik og Waale 2016, s. 266.)

I de neste seksjonene fortsetter fremstillingen av hva muslimene er for noe. Forfatterne konstaterer at muslimene tror på én Gud som har skapt alt og som styrer alt; de konstaterer at muslimene har forpliktelser overfor Gud og mennesker; og de konstaterer at disse forpliktelsene kommer til uttrykk gjennom de fem søyler som er grunnleggende i en voksen muslims liv. I det neste underkapitlet presenteres den islamske tradisjonens viktigste tekster, nemlig Koranen og hadithene, og skillet mellom sunni- og sjia-islam; og i det siste underkapitlet 
presenteres den islamske teologiens kjerne, nemlig troen på Gud, profetene, englene, bøkene og dommens dag. De sentrale doktrinene redegjøres for på en komprimert og skjematisk måte. Når forfatterne kommenterer muslimenes syn på disse doktrinene, så fremstilles de, i all hovedsak, som en samlet gruppe med én felles tro. Dette uttrykkes, blant annet, gjennom valg av kapiteloverskrift («Hva muslimer tror på») og gjennom formuleringer som:

Gud er én og bare én. Dette er det viktigste i muslimenes tro. [...] [M]uslimene ser på Muhammed som den levende Koranen. [...] Muslimer tror at det vil komme en dommens dag, og at det er et evig liv etter døden. [...] Målet for muslimer er å leve et liv i overensstemmelse med Guds ord og komme til paradiset når de dør. (Wiik og Waale 2016, s. 283-284.)

Problematiserende stemmer, på individ- og gruppenivå, synliggjøres i liten grad, og dermed evner ikke kapitlet å realisere læreplanens visjon om at KRLE-faget skal bidra til etableringen av dialogfremmende referanserammer basert på menneskerettighetene. Ann Midttun bekrefter i sin artikkel om dette kapitlet at forfatternes fremstilling av den islamske tradisjonens pluralitet er utilstrekkelig (Midttun 2014). Hennes grundige analyse er riktignok basert på forløperen til KRLE-boka, nemlig RLE-boka fra 2013, men brødteksten i kapitlet om islam har ikke blitt endret.

Wiik og Waale presiserer at det finnes ulike retninger både innenfor sunniog sjia-islam, men dette mangfoldet tematiseres i liten grad (Wiik og Waale 2016, s. 269). Mot slutten av kapitlet formulerer forfatterne noen poenger som kan relateres til en individ- og gruppebasert debatt om hvilke rettigheter den islamske tradisjonen åpner for i møte med modernitetens utfordringer:

Gud har skapt kvinner og menn likeverdige, men de har ulike ansvarsområder og forpliktelser. Disse oppgavene utfyller hverandre. Kvinnen har for eksempel hovedansvaret for oppdragelsen. En mor er høyt ansett og respektert i islam. Mannens oppgave er å forsørge familien, men det betyr ikke at mannen ikke skal hjelpe til i hjemmet. (Wiik og Waale 2016, s. 286.)

Og på den neste siden skriver Wiik og Waale følgende: «Det er i dag en mer vanlig praksis at partene selv finner hverandre og deretter forteller det til familien. Islam forbyr tvangsekteskap» (Wiik og Waale 2016, s. 287). Disse formuleringene kunne inngått som komponenter i den pågående diskusjonen muslimer imellom om hvilke rettigheter og plikter kjønnene egentlig har. Forfatterne følger imidlertid ikke opp disse poengene ved å gå inn i debattene og redegjøre for deres innhold. Kapitlets illustrasjoner bidrar nesten utelukkende 
til å forsterke tendensen i det skriftlige materialet. Bildene viser muslimer som forbereder seg til bønn, utfører bønnen, studerer Koranen eller deltar i andre tradisjonelle aktiviteter (som feiringen av id al-fitr og begravelser).

Nå må det sies til forfatternes forsvar at de i bokens kapitel om filosofi og etikk argumenterer for at en rettighetsfremmende komponent kan gjenfinnes i alle religioner. Forfatterne underbygger denne påstanden ved å henvise til det faktum at alle store religioner har et gjensidighetsprinsipp (Wiik og Waale 2016, s. 31-32). Innenfor islam kommer dette prinsippet til uttrykk, bemerker forfatterne, gjennom Koranens annen sure (vers 279): «Handle ikke urettferdig, og dere skal ikke bli behandlet urettferdig». Dette er et interessant grep; det harmonerer godt med læreplanens formuleringer; og det gir lærere og elever noe å bygge videre på. Problemet med disse refleksjonene er at de ikke relateres til kapitlet om islam og de temaene som behandles der. Samme problem oppstår i det påfølgende kapitlet (som omhandler livssynshumanismen). Her nevner forfatterne den pakistanske nobelprisvinneren Malala Yousafzais kamp for å fremme jenters rett til utdannelse i hjemlandet. Malalas rettighetsprosjekt forankres imidlertid ikke i hennes syn på islam, og det knyttes ikke opp til kapitlet om islam. Dermed fremstår ikke Malala som en representant for rettighetsfremmende strømninger innen islam, men heller som en representant for livssynshumanismen.

\section{Store spørsmål $8-10$}

Store spørsmål er skrevet av Olav Hove, Jørg Arne Jørgensen, Jarle Rasmussen og Marit Sandboe. Verket kom ut mellom 2015 og 2017, og det består av ett bind for hver av ungdomsskolens tre årstrinn. Forfatterne presenterer sin generelle religionsforståelse i det første bindets åpningskapitel, «I begynnelsen var fortellingen». Religioner knyttes opp til menneskets urgamle behov for å gjøre livet forståelig blant annet gjennom myter om høyere makter, verden og mennesket selv. Myter søker å besvare grunnleggende eksistensielle spørsmål som hva er meningen med livet og hva skjer med oss mennesker når vi dør (Hove, Jørgensen, Rasmussen og Sandboe 2015, s. 11). Forfatterne utdyper sitt syn på religiøse tradisjoner ved å presisere at religion ofte handler om troen på én eller flere guder. Tilhørighet til en religiøs tradisjon relateres, som i KRLE-boka, til ut $ø$ velsen av bestemte aktiviteter:

I møte med det hellige tar kristne av seg luen, jødene tar på seg luen, og muslimene tar av seg skoene. Det som er felles, er at mennesker i møte med det hellige ønsker å vise respekt. Når katolikkene skal be, gjør de korsets tegn og kneler. Når det kalles til bønn fra toppen av minareten, legger muslimene seg på kne med hodet mot den hellige byen Mekka. I taket på hotellrommene i Kairo er det grønne piler som hjelper muslimer å plassere bønneteppet i riktig retning. (Hove mfl. 2015, s. 13.) 
Religionenes individ- og gruppenivå synliggjøres ikke i åpningskapitlet. På side 14 skriver riktignok Hove, Jørgensen, Rasmussen og Sandboe at «ikke alt som gir seg ut for å være hellig, fortjener respekt. Eksempler på hykleri og lureri finnes $\mathrm{i}$ alle religioner. Ofte er det mennesker med makt som utnytter sin posisjon til å skaffe seg fordeler» (Hove mfl. 2015, s. 14). I tilknytning til dette avsnittet gjengis et bilde av den norske gatekunstneren Dolk hvor en prest har malt en glorie rundt sitt eget hode. Her antyder forfatterne nærværet av en type kritisk tenkning som kan relateres til et individ- og gruppenivå (uten at det gjøres eksplisitt). Spørsmålet blir, som i forrige seksjon, om et problematiserende individ- og gruppenivå kommer til uttrykk i kapitlet om den islamske tradisjonen.

Kapitlet om islam kommer i det andre bindet, Store spørsmål 9, og det består av fire underkapitler: «Abrahams barn», «Islams historie - Muhammeds liv», «Tradisjon og tro» og «Fra arabisk fellesskap til verdensreligion». Gjennom de fire delene fremstiller Hove, Jørgensen og Sandboe islam som en relativt enhetlig religion (Rasmussen står ikke oppført som medforfatter av det andre og tredje bindet). Samtidig klarer de i større grad enn forfatterne av KRLE-boka å synliggjøre mangfoldet og - ikke minst - uenigheten muslimer imellom. Forfatterne åpner det første underkapitlet med å konstatere at $\ll[\mathrm{m}]$ uslimer tror på én Gud. Islam er derfor en monoteistisk religion, slik som jødedommen og kristendommen» (Hove, Jørgensen og Sandboe 2016, s. 96). På neste side skriver de at å være muslim betyr å leve slik Gud vil; de skriver at det finnes cirka 1,5 milliarder muslimer i verden, og alle har Koranen og profeten Muhammed som ideal (Hove mfl. 2016, s. 97). Samtidig fremhever de at det finnes ulike syn på hvordan man skal leve for å være en god muslim i dag. Denne presiseringen relateres til hva en gruppe muslimske ungdommer fra Norge legger i uttrykket «in sha Allah» («hvis Gud vil»). Noen bruker uttrykket for å signalisere at de underkaster seg Guds vilje; andre bruker uttrykket for å signalisere at Gud spiller en rolle i deres liv, men at de likevel har en betydelig grad av frihet til à velge sine egne livsløp. Forfatterne skriver videre at islam er, på lik linje med jødedommen, en lovreligion, men at det finnes mange tolkninger av lovene. I denne sammenhengen henviser forfatterne til debatten om kvinner bør gå med hodeplagg eller ikke. Forfatterne konstaterer at Koranen ikke er entydig på dette punktet; det blir dermed et fortolkningsspørsmål hvorvidt bruk av hodeplagg bør være påbudt eller ikke.

I den resterende delen av det første underkapitlet nedtones den islamske tradisjonens individ- og gruppenivå til fordel for de overordnede komponentene. Forfatterne redegjør for Guds rolle, sendebudenes rolle og hadithenes rolle. I det neste underkapitlet, som omhandler høydepunkter fra Muhammeds liv, kommer heller ikke individ- og gruppenivået frem i noen nevneverdig grad, men 
i det tredje underkapitlets første seksjon, « $\AA$ følge Profetens sunna», dukker det opp igjen. På side 115 og 116 presenterer forfatterne Malala Yousafzai, og i motsetning til forfatterne av KRLE-boka, så forankrer de Malalas rettighetsprosjekt i hennes syn på islam. Hove, Jørgensen og Sandboe konstaterer at for Malala er den islamske tradisjonen en inspirasjon til å arbeide for jenters rettigheter, og de henviser til et avsnitt $i$ hennes fredspristale (fra desember 2014) hvor hun demonstrerer nettopp dette: «Jeg har lært av den hellige Koranen ordet iqra, som betyr «les», og nun wal-qalam, som betyr «med pennen». Derfor sier jeg at ett barn, én lærer, én penn og én bok kan forandre verden» (Hove mfl. 2016, s. 115). I det tredje underkapitlets påfølgende seksjoner har forfatterne igjen et noe ensidig fokus på islams overordnede nivå. De presenterer de fem søylene, det sentrale trosgrunnlaget og Koranen på en fortettet og standardisert måte. Når forfatterne kommenterer muslimenes syn på disse elementene, så fremstilles de (nok en gang) som en temmelig samlet gruppe:

Du kan spørre muslimer hvor som helst $i$ verden, en lard som kan Koranen og hadither utenat eller en ungdom på gata, og du vil oppdage at de er enige om [troen på Gud, Guds engler, Guds profeter, Guds bøker, dommens dag og et liv etter døden]. (Hove mfl. 2016, s. $120-121$.

I det siste underkapitlet, «Fra arabisk fellesskap til verdensreligion», synliggjøres imidlertid både individ- og gruppenivået langt tydeligere, og det gjøres på en måte som imøtekommer læreplanens formuleringer. Hove, Jørgensen og Sandboe redegjør først for skillet mellom sunni- og sjia-islam, og så inkluderer de en egen seksjon om sufismen. Deretter går forfatterne inn i debatten muslimer imellom om hvordan man bør forholde seg til moderniteten. De presenterer de islamske fundamentalistenes $\emptyset$ nske om å vende tilbake til den «opprinnelige» religionen - et $\emptyset$ nske som ofte kombineres med en kritikk av moderne (vestlige) verdier som ytringsfrihet, religionsfrihet og likestilling. Forfatterne konstaterer at islamske fundamentalister har drevet aktiv misjon i blant annet Norge, og at en del norske muslimer har valgt å støtte deres forståelse av islam. Samtidig presiserer forfatterne at mange muslimer tar avstand fra fundamentalistiske fortolkninger og diskuterer hvordan muslimske verdier kan kombineres med humanistiske verdier og menneskerettigheter. I denne sammenhengen nevner forfatterne Faten Mahdi al-Hussaini, Amal Aden og Kadra Yusuf som eksempler på unge norske muslimer som prøver å ta et oppgjør med undertrykkende holdninger blant deres egne (Hove mfl. 2016, s. 131-133).

Det bør også nevnes at Hove, Jørgensen og Sandboe presenterer denne tematikken på nytt i Store spørsmål 10. De avslutter det siste bindet med et repetisjonskapitel hvor de gjentar noen av elementene forbundet med de fem 
verdensreligionene. Mot slutten av seksjonen om islam konstaterer forfatterne - under overskriften «Reformasjon av islam?» - at mange går inn for reformer slik at den islamske tradisjonen kan omfavne humanistiske idéer. Reformvennlige muslimer mener at Koranen og profetens sunna må tolkes på måter som harmonerer med moderne verdier. Forfatterne nevner den muslimske feministen Sofia Rana som et eksempel. Hun representerer et norsk-pakistansk nettverk som arbeider for trosfrihet og homofiles rettigheter. Sofia mener, skriver forfatterne, at det er et generasjonsopprør på gang i det norsk-pakistanske miljøet, og at imamer i mange moskéer står for reaksjonære og utdaterte holdninger (Hove, Jørgensen og Sandboe 2017, s. 226). Illustrasjonene i kapitlet om islam og i repetisjonsseksjonen om samme religion gjenspeiler tendensen $\mathrm{i}$ tekstmaterialet. Noen bilder viser muslimer som deltar i tradisjonelle religiøse aktiviteter, mens andre bilder viser muslimer, deriblant Faten Mahdi al-Hussaini, som kjemper mot undertrykkende holdninger og for menneskerettigheter.

\section{Avsluttende kommentarer}

På grunnlag av mine analyser kan jeg konstatere at kapitlet om islam - i kombinasjon med repetisjonskapitlets seksjon om samme religion - i Store spørsmål indikerer eksistensen av kritiske strømninger i sterkere grad enn kapitlet om islam i KRLE-boka (hvor problematiserende stemmer er nesten totalt fraværende). Store spørsmål inkorporerer dermed læreplanens visjon om at KRLE-faget skal bidra til etableringen av dialogfremmende referanserammer basert på menneskerettighetene - i hvert fall et stykke på vei. Forfatterne av Store spørsmål burde kanskje hatt med noen flere detaljer om debattenes innhold, men de signaliserer på en tydelig måte at viktige debatter muslimer imellom faktisk pågår, og de gjør det innenfor rammene av kapitlet og repetisjonsseksjonen om islam. Dette gir lærere og elever noe å bygge videre på i arbeidet med å utvikle en nyansert forståelse av islams sammensatte rolle i den moderne verden.

En åpenbar innvending mot pluraliserende fremstillinger av islam er at mange muslimer nok vil oppfatte kritiske stemmer som forfatterne av Islamsk humanisme eller, for å ta et eksempel fra Store spørsmål, Sofia Rana som såpass radikale at de faller utenfor den islamske tradisjonen. Utgangspunktet for Robert Jackson (hvis tredelte tilnærming har vært mitt teoretiske fundament) er imidlertid å vise at selv debattanter med svært problematiserende tilnærminger til sine respektive tradisjoner kan være en del av religions- og livssynsfaget uten at undervisningen gir et forvrengt bilde av disse tradisjonene. Heller tvertimot - å ha med slike stemmer er viktig ikke bare for å demonstrere islams (og andre religioners) bidrag til en nasjonal og internasjonal menneskerettighetsdiskurs, men også for å vise islams (og andre religioners) motsetningsfulle mangfold. 
Helt til slutt bør jeg - nok en gang - kommentere KRLE-fagets nye læreplan som vil gjelde fra høsten 2020. Gjennom min analyse prøver jeg å vise at læreplanens visjon om etablering av felles referanserammer basert på menneskerettighetene kan - riktig forstått - imøtekomme elevers ønske om mer nyanserte fremstillinger av den islamske tradisjonen. Hvis denne visjonen ikke videreføres i den nye læreplanen, så kan min analyse miste noe av sin relevans. På side 2 har jeg imidlertid konstatert at denne visjonen vil bli videreført. I den nye planens første seksjon står det, som nevnt, at elevene skal bli kjent med felles dialogfremmende verdier og hvordan disse verdiene er forankret i ulike religioner og livssyn (Utdanningsdirektoratet september 2019). Slike formuleringer kan, som allerede fastslått, generere nye og spennende perspektiver hvis innhold vil potensielt sett - $\emptyset$ ke KRLE-fagets betydning i vårt flerkulturelle samfunn.

\section{LITTERATUR}

Fakhry, Majid. 2004. A History of Islamic Philosophy. New York: Columbia University Press.

Furseth, Inger (red.). 2015. Religionens tilbakekomst $i$ offentligheten? Oslo: Universitetsforlaget.

Goodlad, John (red.). 1979. Curriculum Inquiry. The Study of Curriculum Practice. New York: McGraw-Hill Book Company.

Gule, Lars. 2006. Islam og det moderne. Oslo: Abstrakt forlag.

Hove, Olav, Jørgensen, Jørg Arne, Rasmussen, Jarle og Sandboe, Marit. 2015-2017. Store Spørsmål 8-10. Oslo: H. Aschehoug \& Co.

Jackson, Robert. 1997. Religious Education. An Interpretive Approach. London: Hodder \& Stoughton.

Jackson, Robert. 2004. Rethinking Religious Education and Plurality. Issues in Diversity and Pedagogy. London: RoutledgeFalmer.

Juuhl, Gudrun Kløve, Hontvedt, Magnus og Skjelbred, Dagrun. 2010. Læremiddelforsking etter LKo6. Eit kunnskapsoversyn (Rapport nr. 1/2010). Høyskolen i Vestfold.

Lippe, Marie von der. 2010. Youth, Religion and Diversity. A Qualitative Study of Young People's Talk about Religion in a Secular and Plural Society. Doktorgradsavhandling, Universitetet i Stavanger, Stavanger.

Lippe, Marie von der. 2013. «Hvordan snakker ungdom om religion og hvorfor snakker de sånn? » i DIN - Tidsskrift for religion og kultur nr. 2, side 7-31.

Lippe, Marie von der og Undheim, Sissel (red.). 2017. Religion i skolen. Didaktiske perspektiver på religions- og livssynsfaget. Oslo: Universitetsforlaget.

Mayer, Ann Elizabeth. 2007. Islam and Human Rights. Boulder: Westview Press.

Midttun, Ann. 2014. «Biter og deler av islam» i Norsk Pedagogisk Tidsskrift nr. 5, side 329-340.

Reiss, Ellen og Noor, Linda (red.). 2016. Islamsk humanisme. Oslo: Moment. 
Roald, Anne Sofie. 2012. Islam. Oslo: Pax Forlag.

Skrunes, Njål. 2010. Lœrebokforskning. En eksplorerende presentasjon. Oslo: Abstrakt forlag.

Tallaksen, Inger Margrethe og Hodne, Hans. 2014. «Hvilken betydning har læremidler i RLE-faget?» i Norsk Pedagogisk Tidsskrift nr. 5, side 352-363.

Toft, Audun. 2019. Conflict and Entertainment. Media Influence on Religious Education in Upper Secondary School in Norway. Doktorgradsavhandling, MF vitenskapelig høyskole, Oslo.

Utdanningsdirektoratet. 2008. Lereplan $i$ religion, livssyn og etikk. Oslo: Utdanningsdirektoratet.

Utdanningsdirektoratet. 2015. Lœreplan i kristendom, religion, livssyn og etikk. Oslo: Utdanningsdirektoratet.

Utdanningsdirektoratet. 2019. Ny læereplan i kristendom, religion, livssyn og etikk. Oslo: Utdanningsdirektoratet.

Vogt, Kari, Larsen, Lena og Moe, Christian (red.). 2009. New Directions in Islamic Thought. London: I. B. Tauris \& Co.

Wiik, Pål og Waale, Ragnhild Bakke. 2016. KRLE-boka 8-10. Oslo: Cappelen Damm. 